\title{
Transport Interchanges Effects on their Surroundings in Tunja (Colombia) and Cordoba (Spain): A Comparative Approach
}

\author{
Sonia E. Díaz ${ }^{1}$, José M. de Ureña ${ }^{2}$ and Cecilia Ribalaygua ${ }^{*} 3$ \\ ${ }^{I}$ Pedagogical and Technological University of Colombia, Avda Central del Norte s/n. Tunja, Colombia \\ ${ }^{2}$ University of Castilla La Mancha. Avda Camilo José Cela s/n, 13002 Ciudad Real, Spain \\ ${ }^{3}$ University of Cantabria. Avda de los Castros, 44, 39005, Santander, Spain
}

\begin{abstract}
This article proposes a methodology to study the urban implications of transport interchanges. The methodology was evaluated through the study of commercial establishments and urban quality in the surroundings of two transport interchanges. The case studies are a bus station in Colombia and a combined high-speed rail and bus station in Spain. The article draws two types of conclusions; firstly, that the comparative methodology proposed is effective in determining the influence of transport interchanges and secondly that it provides specific conclusions about the activities in the station's surrounding area. The article demonstrates that the surroundings of the transport interchanges have greater commercial activity than similar areas of the city. It also concludes that the different income levels of HSR and bus users provoke a variety and quantity of commercial activities within each type of station. Furthermore, it concludes that the perceived quality of the interchange surroundings is deeply influenced by its level of integration within the urban plan, despite the negative side effects related to transport.
\end{abstract}

Keywords: Urban implications, public space quality, transport interchange, bus station, high-speed rail station, Spain, Colombia.

\section{INTRODUCTION}

Transport interchanges attract some activities and repel others. Some activities benefit from being situated along the flows of people and vehicles to/from interchanges because they are potential clients. Similarly, good accessibility is of positive value for residential and tertiary activities. In contrast, large flows of vehicles and people and transportation technology barriers generate repulsion of certain activities. This "love-hate" aspect is an innate characteristic of transport interchanges [1].

The urban consequences of each urban interchange depend on its territorial location and will be a mixture of what it attracts and repels and of the evolution processes of the city. This article evaluates the methodological approaches for studying the urban implications of transport interchanges that have been described in scientific literature.

Developing an appropriate methodology to study the urban effects of interchanges is necessary because an increasing number of cities are relocating their existing interchanges or establishing new ones. In many cases these relocated or new interchanges are related to the introduction of new transportation modes, for instance high-speed rail. The article reviews the existing scientific literature on the topic in order to propose an improved methodology to understand the complex relationships between transport interchanges and their specific territory.

*Address correspondence to this author at the University of Cantabria. Avda de los Castros, 44, 39005, Santander, Spain; Tel: +34 926295300;

Fax:+34 926295391; E-mail: Cecilia.ribalaygua@unican.es
The methodology is designed to provide an understanding of the interchanges influence on commercial establishments and on urban quality in their surroundings as a result of the users attracted and how the interchange is considered in the city plan. This article evaluates the proposed methodology appropriateness by contrasting two case studies in Córdoba (Spain) and Tunja (Colombia). The study of two extremely different cases, allows not only a compared analysis between both of them, but also proves the versatility of the methodology in order to cover different situations and territorial processes around transport interchanges.

The article presents, first of all, the literature review on the territorial implications of transport infrastructures in general and also of transport interchanges in particular. Secondly, the article describes the proposed methodology and the specifics characteristics of the two interchanges compared in the study. Third, the article analyses the similarities and differences between the two case studies, specifically in terms of economic activity and the perception of urban quality in the surroundings of each interchange.

\section{IMPLICATIONS OF TRANSPORT INTER- CHANGES: REVIEW OF LITERATURE}

Methodologies for studying the implications of transport infrastructures differ according to the implications analyzed, which can be classified into three groups: economic development, space structure and territorial dynamics [2]. These studies also conclude that changes in transportation components do not necessarily produce substantial territorial changes $[3,4]$. 
The first group of studies is frequently undertaken to determine how transport infrastructures influence a geographic area's economic development: either total investment in transport infrastructures [5-7] or a specific infrastructure $[8,9]$. The most commonly analysed impacts are productivity improvements derived from generalized transport cost reductions and increasing accessibility [10, 11]. Banister [12] proposes three scales of analysis: macroeconomic (impact on economic growth), meso-economic (impact on urban growth) and micro-economic (impact on real estate values). Although models and economic indicators $[9,13]$ are the most common research methods, there are also historical revisions [14].

The second group of studies determines in which ways transport infrastructures influence the spatial distribution of population and activities. Methods vary from reviews of previous investigations $[15,16]$, monographic descriptions of case studies [17-19], comparative analysis among cities [20], and historical analysis [17], but the most common is models [21-25]. Wolfram [20] analyses how transportation projects are considered by metropolitan land use plans.

The third group of studies determines in which ways transport infrastructures influence territorial dynamics over a time period. For urban modifications Bosch and Ulied [26] used a 15-year period before and after the implementation of the infrastructure and Serrano, et al. [27] and Ureña, et al. [28] propose four time periods: before the creation of the infrastructure becomes public knowledge, once it is known but before it has been implemented, during the first five years of operations and the following ten years.

In the types of studies mentioned above [4, 5, 27, 29, 30] four drawbacks can still be observed:

- Explanation of a territorial effect based solely on the characteristics of transport.

- Difficulty of comparing the results obtained when using different types of analysis and different ways of measuring the variables under study.

- Analysis of territorial elements which are difficult to measure, given the complexity of their interrelations.

- $\quad$ Lack of knowledge about the dynamics before and after the development of the infrastructure.

On the other hand, studies on the implications of transport interchanges in their surroundings have considered several aspects: the location of activities [24, 31, 32], the image of the area [30,33], the real estate values [21, 34-36], the urban restructuring [17, 37-39] and the interchange's specific characteristics [40,41]. These studies used similar types of analysis and methodologies to those described above.

A study of the urban influence of transport interchanges has to consider the specific characteristics of each interchange. To define these characteristics the scientific literature classifies urban interchanges on the basis of:

- Location in the urban structure and integration in the city plan

- Characteristics of the affecting and affected territory

- $\quad$ Available means of transportation

\section{- $\quad$ Available services to travellers and non-travellers}

There is no consistency in the location classifications. Grebert et al. [41] use the type of land they are located on (urban, rural, borders, etc.). Said et al. [42] and Menerault [43] use the distance to the city centre, Lambooy [44] also includes the city size and Bourgeois, et al. [45] and Ribalaygua [46] consider the connections to other means of transport, areas and/or activities.

Regarding the characteristics of the territory, Ureña, et al. $[39,47]$ classify the cities according to their size and distance to metropolitan areas, Bourgeois, et al. [45] use the city size and the hierarchy of the interchange in the transportation network, and Said, et al. [42] incorporate the development potential of the area surrounding the interchange.

In relation to the available means of transportation Godard [48] classifies interchanges considering the existing modal combinations and Said, et al. [42] also includes the territorial scales (local, regional, etc.) of existing transportation means.

Other services, besides transportation ones, may be offered for travellers and non-travellers at interchanges. Soulas [49] and Burckhart [50] classify interchanges depending on the availability and type of these additional services.

\section{COMPARATIVE METHODOLOGICAL APPROACH}

The main methodological limitations of the abovementioned studies when used to understand the implications of urban interchanges in their surroundings can be summarized as: to attempt to establish a direct and biunivocal relationship between the transport infrastructure and the territory $[4,8,10,12,51,52]$ and to do so without being aware the importance of the territorial dynamics before and after the implantation of the transport infrastructure [27, $53,54]$.

To overcome these limitations we suggest an approach that is capable of the following features:

- Identifying how the transportation changes and their derived aspects are being "absorbed" into territorial transformations.

- Characterizing the role of the interchange at the local, regional and national scales.

- Explaining the territorial effects not only as a consequence of the interchange characteristics.

- Understanding the evolving interrelation between transport and territory throughout two periods of time, before the interchange comes into service-before and after the decision to create it- and after its implementation -five and ten years after.

There are two types of methodologies capable of including these principles. First, historical studies of the evolution of transport and territory on the three abovementioned scales, throughout the four periods of time and including sufficient surveys of the agents involved and statistical analysis over all four periods of time. Second, a comparative analysis of several interchanges which are 
similar in many aspects and different in a few others related to the effects that will be studied.

The first methodology is the one that is really aimed at understanding the transport-territory interrelation processes. This is why some studies were undertaken before some new French High-Speed Rail lines were built, with the objective of repeating them several times in the subsequent years [55]. Often studies are only undertaken after the transport element is built and/or comes into service and so it is very difficult to maintain the scientific principles and to obtain precise information about the economic activities and trips before the interchange was operational. This is why the article evaluates the second alternative.

The comparative methodology proposed is developed in two phases. In the first phase, the evolution of the territorial and transport interchange elements is analyzed on the interurban, urban and intra-urban scales (micro-local scale), along with the characteristics of the interchange itself as far as there is information available; with the aim of determining the type of interchange and the differences and similarities between the cases that are being compared. The second phase deals with the comparative analysis of the territorial elements of the surroundings that might have been influenced by each interchange with the aim of inferring the incidence of the incorporation of the infrastructure in the area from the differences detected among the cases under study.

In summary, the methodology proposed is structured in two phases to deal with the two types of analysis described: phase 1, which, using dynamic analyses, identifies the type of interchange, and phase 2, which uses a comparative static analysis of the quantity and variety of commercial establishments and of the quality of urban space around each interchange.

\section{CASE STUDY (PHASE 1): SPECIFICS OF THE INTERCHANGES AND THEIR TERRITORIAL CONTEXTS}

The article proposes to compare two urban interchanges that are similar in their local-urban, regional and national location and dynamics ${ }^{1}$ (phase 1 of the proposed methodology) and differ in their transportation means and in their integration in the city plan.

The purpose is to deduce their capacity to attract economic activities and to qualify the urban space in their surroundings (phase 2 of the methodology).

The selected cases are the combined High-Speed Rail (HSR) and Bus station in Córdoba, Spain, and the Bus terminal in Tunja, Colombia. Both are in intermediate size cities and have been operating long enough (see Table 1) to observe the changes in their surroundings (see [27]). Only one transport interchange includes a new means of transportation (the HSR in Córdoba, Spain).

To avoid the effect of the countries' socioeconomic differences the comparison was not made between the two

\footnotetext{
${ }^{1}$ We understand by dynamics the evolution of the role of each city in their national and regional context and of the interchanges in their city urbanlocal contexts.
}

cases but instead against the average characteristics of each city.

Both cities have a similar position in the transportation network, being the primary access "gate" to large territories. Córdoba provides the main rail and road access to west Andalucía and provides a connection between Madrid (400 $\mathrm{km})$, Seville $(138 \mathrm{~km})$ and Malaga $(160 \mathrm{~km})$. Tunja is on the national road network that provides connections between Bogota $(120 \mathrm{~km})$ and the northeast region of Colombia (Bucaramanga and Cúcuta). See Fig. (1) and Table 1.

In Córdoba, the HSR has been the main factor in travel time reductions to Madrid (68\%), Sevilla (50\%), and Malaga $(59 \%)$. In Tunja, significant travel time reductions were produced by road improvements (i.e. $53 \%$ to Bogotá in the last 50 years). Although Córdoba is located $400 \mathrm{~km}$ from Madrid and Tunja only $120 \mathrm{~km}$ from Bogota, both cities are two hours away from their corresponding national capital (see Table 1).

The interurban connections provided by the interchanges are crucial for the economies of both cities because their main activities are commerce, public administration and university education, while Córdoba is also a tourist city (see Table 1).

Regarding the interchange locations and their integration within the city, both stations were located on what was the edge of the city at the time of creation and as a result of urban growth are now on the edges of their central business districts, close to the city centre (see Fig. 2 and Table 1). The combined HSR-Bus interchange in Córdoba was located in 1994 on the edge of the central business district, beside the old 1860 rail station located at that time on the edge of the city, and the Tunja Bus interchange was located in 1969 near the road by-pass on the edge of the city.

The integration of the two interchanges in the urban plan has been done with almost opposite strategies. In Córdoba, the RENFE plan (see Table 1) was implemented upon the arrival of the HSR to remove the urban barrier caused by the railway tracks (locating the railway lines underground), to add major citywide urban structural elements (a park and a ring road) and to interconnect the two sides of the city that were previously separated by the railway barrier [39].

In Tunja, the construction of the bus station included the passenger platforms and the building, but no investments were provided to improve the stations' surroundings and the access streets (bus access is done along two 6.5-metre wide streets and a 7.5-metre wide inter-city by-pass). Moreover, the last three Tunja city plans (1976, 1987 and 2001) described the bus terminal as inefficient and causing pollution, traffic congestion and environmental degradation and proposed relocating it further from the city centre, by the new inter-city highway (see Fig. 2b), although this relocation has not taken place.

On the other hand, regarding the interchange characteristics, in Córdoba it includes both the HSR and Bus stations, but it is the HSR that stands out more in the urban landscape and image because it incorporates a new transportation technology, even though, only one third of the 
Table 1. City and Interchange Characteristics

\begin{tabular}{|c|c|c|}
\hline & Córdoba (Spain) & Tunja (Colombia) \\
\hline \multicolumn{3}{|l|}{ Similarities } \\
\hline Transportation Role of City & Gate to West Andalucía & Gate to North East Region \\
\hline Main Activities of City & Tourism, University and Provincial Capital & University and Departmental Capital \\
\hline Location of Interchange & $\begin{array}{l}\text { Edge of CBD ( } 900 \text { metres from Tendillas } \\
\text { Square) }\end{array}$ & Edge of CBD ( 400 metres from Bolivar Square) \\
\hline Relation to previous location of Interchange & $\begin{array}{l}\text { Adjacent to } 1860 \text { Train Station on the edge of the } \\
\text { city at that time }\end{array}$ & $\begin{array}{l}\text { Previous Bus Stops around Market Square } \\
\text { around Bolivar Square }\end{array}$ \\
\hline Passengers per year & 10 million, $66 \%$ bus passengers & 4 million \\
\hline Daily services to national capitals & 33 on HSR and 6 on bus & 160 on bus \\
\hline \multicolumn{3}{|l|}{ Differences } \\
\hline Means of Interurban Transport at Interchange & Bus, Train \& High-Speed Rail (HSR) & Bus \\
\hline Relation to City Plan & $\begin{array}{l}\text { "Renfe" } 90 \text { Has a redevelopment plan to } \\
\text { integrate the interchange }\end{array}$ & $\begin{array}{l}\text { No specific urban adaptation plan for the } \\
\text { interchange surroundings }\end{array}$ \\
\hline $\begin{array}{l}\text { Services offered at HSR station (apart from } \\
\text { coffee shops) }\end{array}$ & $\begin{array}{l}-1 \text { restaurant } \\
-2 \text { snack stands } \\
-7 \text { retail stores (clothes and gifts) } \\
-7 \text { service companies (car rentals, tourist } \\
\text { information, etc) }\end{array}$ & \\
\hline
\end{tabular}

10 million passengers per year are railway users ${ }^{2}$ (see Table 1). In Tunja it includes only bus transportation, with 4 million passengers per year. Both interchanges provide abundant transportation services to the national capital and to most regional destinations and less numerous services to other more distant cities.

Comparing HSR and bus travel times and fares (see Table 1) it can be observed that passengers using the longdistance HSR are of a higher economic status than the bus ones.

In terms of services offered to travellers and nontravellers, in the Córdoba interchange there is a remarkable difference between those offered by the HSR and Bus stations, with a wide variety of high-quality commercial activities in the HSR station, whereas the neighboring bus station has fewer stores of a clearly inferior quality. In Tunja, there are only snack stands, and they are more numerous, smaller and of low quality. See Table 1.

${ }^{2}$ According to the information provided by the Bus Station Administration and RENFE for 2008.

\section{CASE STUDY (PHASE 2): COMMERCIAL ACTIVITIES AND PERCEPTION OF URBAN QUALITY}

This second phase of the proposed methodology corresponds to a static analysis (current circumstances) comparing the nearby territorial elements, specifically in terms of commercial activities and the perception of urban quality.

The information required about the two case studies was obtained from three studies: a plot inventory, a perception survey and a commercial establishment survey.

In Córdoba, the three studies were undertaken in an 800metre long strip adjacent to the station north and south of the new street, park and underground railway tracks of the RENFE plan (Fig. 3a). In Tunja, the study area was defined as a circle with a $250 \mathrm{~m}$ radius around the bus terminal (Fig. 3b). A smaller area was used in Tunja because of the smaller size and shorter distance to the city centre. In the two cases, the area of the study fulfils the criterion of walkable distance used in similar studies $[1,31,32]$. Although studies 


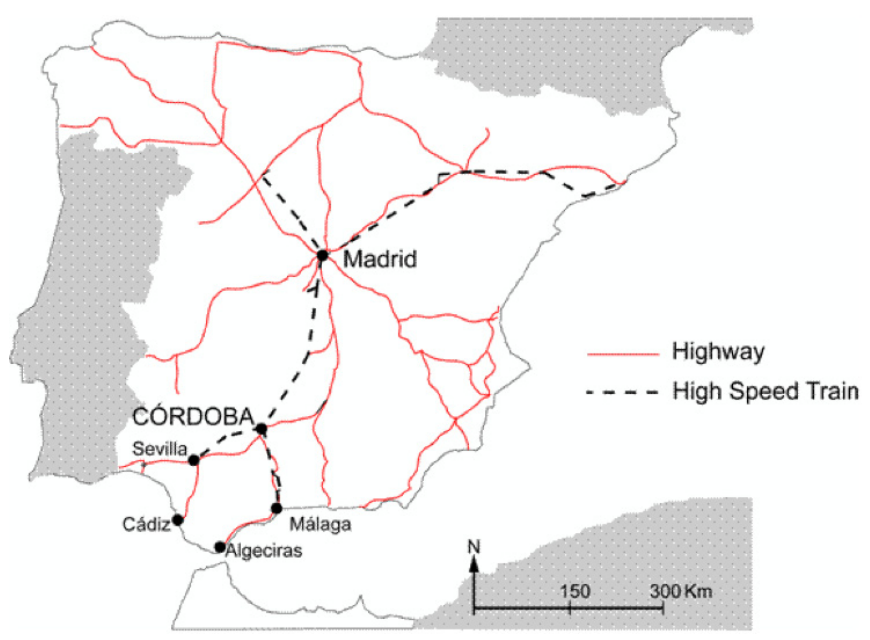

Fig. (1a). Connection between Córdoba and Madrid and west Andalucía. Source: authors.

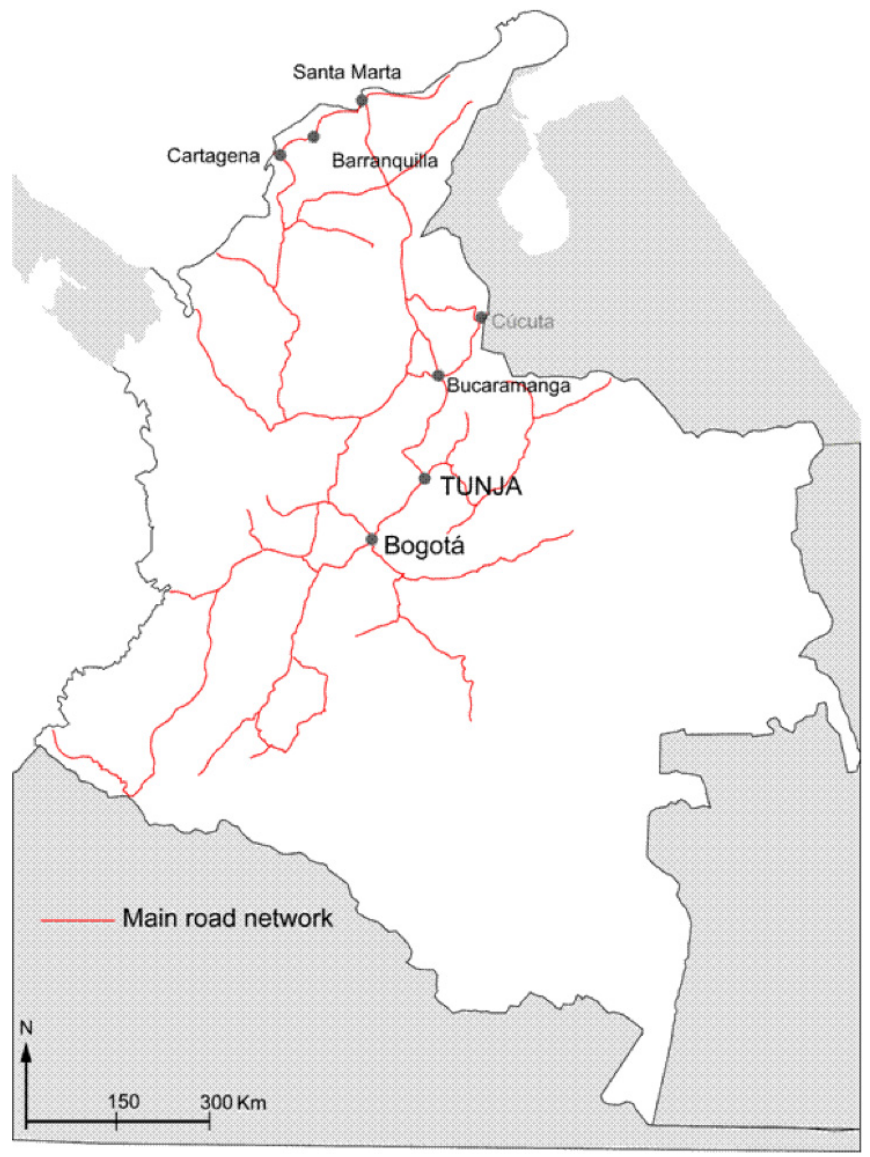

Fig. (1b). Connection between Tunja and Bogota and the northeast part of Colombia. Source: authors.

often use a circular area as the study zone, in the Cordoba case, the rectangular area of the RENFE Plan is used, as this plan determined the inclusion of the interchange within the urban plan.

The plot inventory was undertaken in Tunja (year 2008) and Córdoba (year 2009) to compile the total surface area of each building and their use (residential, commercial, mixed residential/commercial or institutional). If there was any commercial activity, its nature was also noted (e.g., product sale, services, restaurants, hotels). Additionally, the quality (low, medium, high) of the existing establishments was observed relative to the average quality level of similar services in each city.

Commercial establishments were surveyed in both cities (year 2008) to collect data about their clients (travellers, interchange workers, residents, tourists, workers from other companies), and about the bystanders opinion of the urban quality of each study area compared with the urban quality of the entire city.

Considering the number and type of existing establishments in each study area (see Table 2), the survey sample size was designed according to sampling theory, with $90 \%$ confidence level and 10\% error, and 52 surveys were carried out in Córdoba and 122 in Tunja ${ }^{3}$. For the perception survey, 60 passers-by were surveyed in each case, taking into account that no type of stratification was necessary, that the study areas were small and that those questioned had a suitable level of knowledge about the area to provide an opinion about their perception [56, 57].

\subsection{Commercial Activity Results}

The plot inventory revealed that $61 \%$ of the plots in Córdoba and $33 \%$ in Tunja contained some type of commercial establishment. The number per hectare in the whole city of Cordoba was 2.0 and 3.5 in Tunja, whereas in the study areas it was five and three times greater respectively (Table $\mathbf{2}$ ).

Table 2. Commercial Establishments Per Hectare in Study Cases

\begin{tabular}{|c|c|c|c|}
\hline & Zone & Córdoba & Tunja \\
\hline \multirow{2}{*}{$\begin{array}{l}\text { Number of commercial } \\
\text { establishments }\end{array}$} & City & $9,305^{\mathrm{a}}$ & $7,875^{\mathrm{c}}$ \\
\hline & Study area & $179^{\mathrm{b}}$ & $228^{\mathrm{b}}$ \\
\hline \multirow{2}{*}{ Area (hectares) } & City & 4,696 & 2,244 \\
\hline & Study area & 18.1 & 21.9 \\
\hline \multirow{2}{*}{$\begin{array}{l}\text { Commercial establishments } \\
\text { per hectare }\end{array}$} & City & 2.0 & 3.5 \\
\hline & Study area & 9.9 & 10.4 \\
\hline
\end{tabular}

However, since the mixed residential/commercial uses and densities in the urban areas produced large variations in the average number of commercial establishments per hectare, another comparison was required. In Cordoba, considering the number of commercial establishments per hectare in each postal zone ${ }^{4}$ (Fig. 4a), those zip-code zones

\footnotetext{
${ }^{3}$ The sample size was designed for proportions, using the formulation $\left[Z^{2 *} N^{*} p * q /\left((N-1) * B^{2}+Z^{2 *} p^{*} q\right)\right]$. In the case of Cordoba the sample was designed without stratification; although in Tunja the establishments were grouped by type of economic activity so a more detailed study was done in this city, which is not the aim of this article.

${ }^{4}$ The Chamber of Commerce of Cordoba provided the number of commercial activities but not the number of establishments; hence we will assume that each establishment fulfills 1,1 activities. This value $(1,1)$ is obtained by dividing the number of activities in Córdoba $(10,149)$ by the
} 


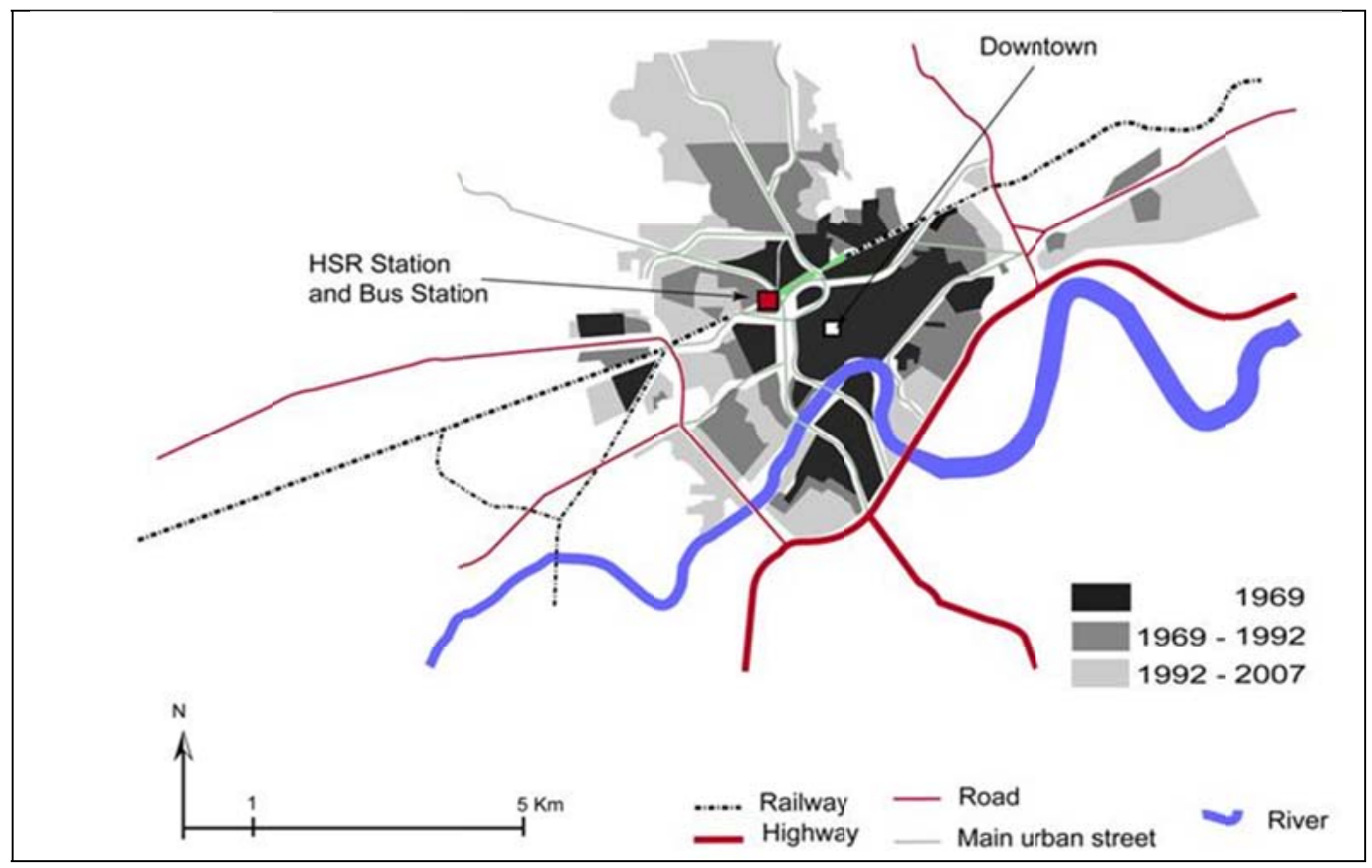

Fig. (2a). Spatial growth of Córdoba and location of the transport interchange. Source: authors.

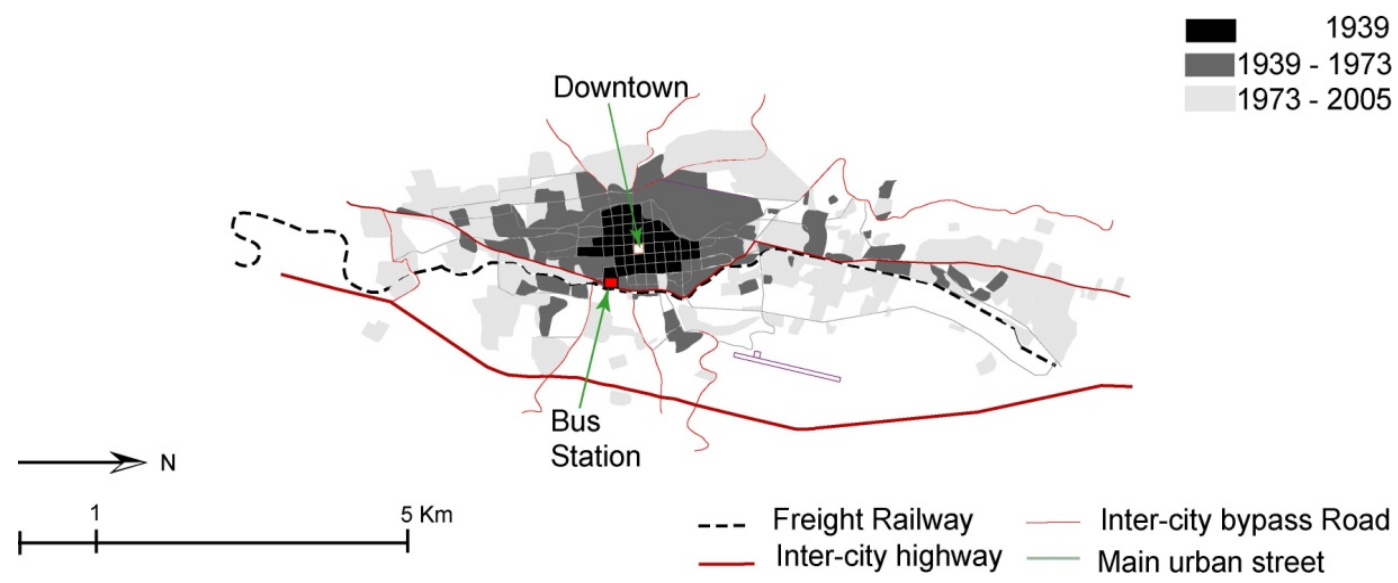

Fig. (2b). Spatial growth of Tunja and location of the transport interchange. Source: authors

located in the city centre (near Tendillas Square, postal zones: 14008 and 14003) had the greatest number of commercial establishments per hectare (21.1 and 10.4, respectively), whereas the study area contained more establishments per hectare (9.9) than other zip-code zones, even some areas that were also near the city centre (postal zones: 14001 and 14002). In Tunja, considering the sectors defined by the National Department of Statistics (Fig. 4b), the city centre sector (where Bolívar Square is located) shows that $56 \%$ of plots had some type of commercial establishment, whereas in the study area the percentage was $33 \% \%^{5}$, the second largest value in the city. Comparing the study areas with the other areas of both cities at similar distances from the city centre it can also be seen that the latter had lower densities of commercial establishments than the study areas. This means that the areas around the

number of commercial establishments $(9,305)$ in the two cases for retail trade, food-beverage services, real estate and business services in 2008.

${ }^{5}$ Plot inventory of Tunja (2008). interchanges concentrate commercial establishments, which could be attributed to the presence of the interchanges.

The composition of commercial customers, excluding establishments inside the interchanges, (see Fig. 5) in Tunja shows that the existing establishments correspond to the presence of the bus terminal, because $47 \%$ of clients are residents and $39 \%$ are passengers or station employees. Whereas in Cordoba this is not so, because the interchange users represent only $5 \%$ of clients (including tourists using the interchange $)^{6}$ while a large percentage are residents $(57 \%)$ and tourists $(38 \%)$.

The distribution of commercial establishments in each study area according to their type of activity differs from that of each city as a whole (Fig. 6). In each city as a whole, there

\footnotetext{
${ }^{6}$ The tourists that use the transport interchange immediately before or after a commercial establishment are classified as station passengers, while tourists that do not do so are classified as tourists.
} 


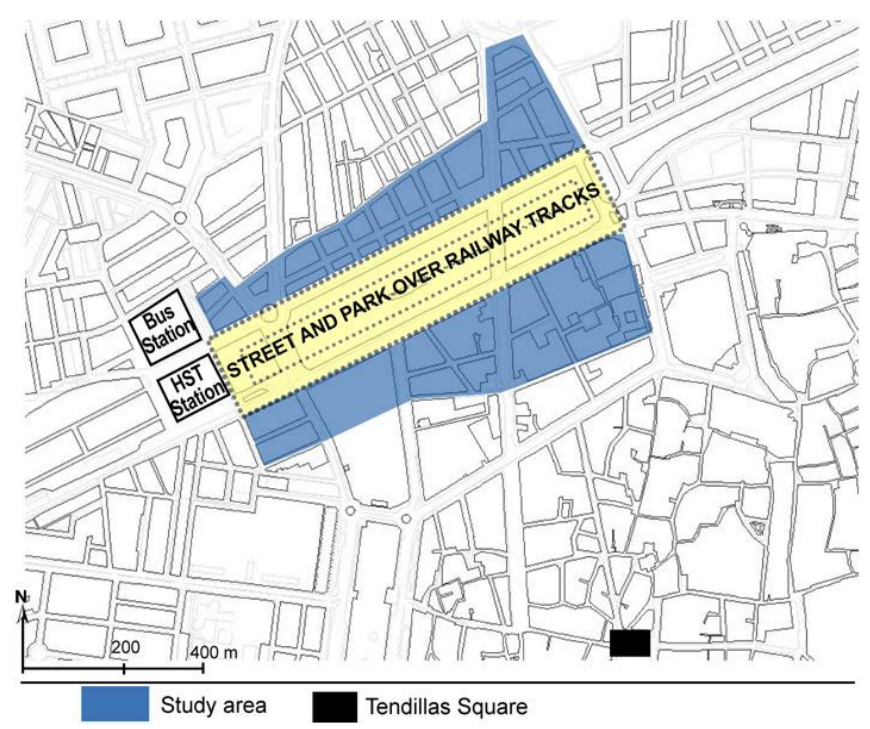

Fig. (3a). Study Area - Córdoba, Spain. Source: authors.

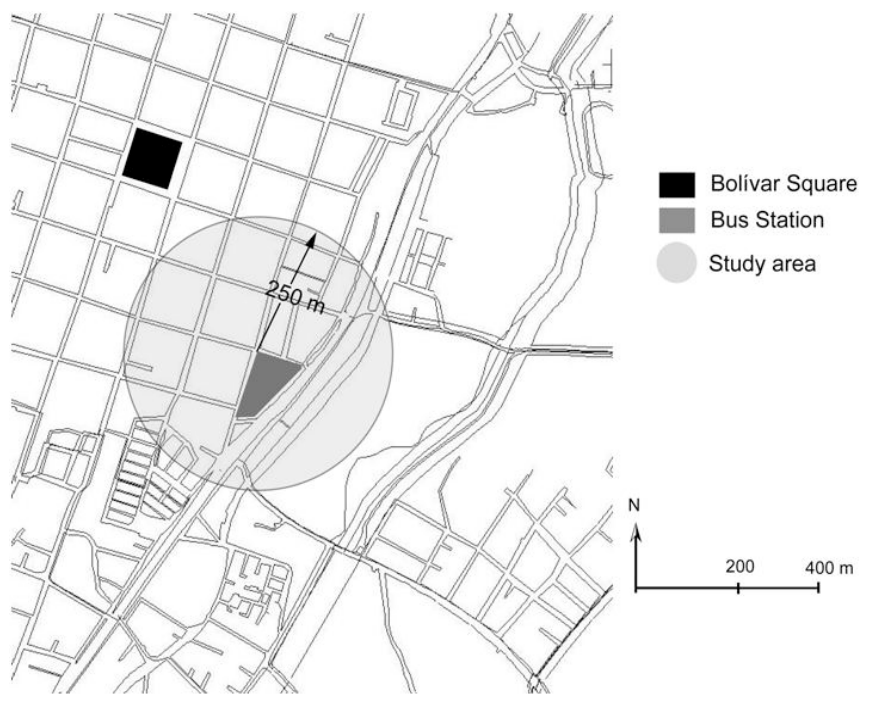

Fig. (3b). Study Area-Tunja, Colombia. Source: authors.

is a clear predominance of product-sale stores ( $58 \%$ in Tunja and $49 \%$ in Córdoba), whereas in each study area there is a more equal distribution of product sales and services $(38 \%$ and $35 \%$ in Tunja; $34 \%$ and $36 \%$ in Córdoba, respectively). It is also evident that the interchange areas show a reduction in the percentage of product sales and an increase in the number of those that offer services. An increase is also observed in the percentages of restaurants and hotels in the interchange areas. This last fact is more obvious around the bus terminal in Tunja, because in the city the percentage of restaurants is low $(12 \%)$, whereas in Córdoba there is a higher percentage of this type of establishments due to tourism $(26 \%)$.

\subsection{Urban Quality Perception Results}

In Cordoba, several strategies were implemented to encourage the integration of the transport interchange with its surroundings, reducing the negative effects of the train and buses by locating the rails underground and building a new six-lane ring road and improving the urban area quality. Conversely, the lack of such corrective actions in Tunja resulted in a low quality urban area around the bus terminal.
The quality perception survey shows a much better perceived quality in the surroundings of the Cordoba interchange than in Tunja. In Cordoba $26 \%$ considered the study area to be of better quality than the city average and $12 \%$ considered it worse, whereas in Tunja there was almost an opposite perception, with $41 \%$ considering it to be of lower quality and only $10 \%$ of better quality. Moreover, there is a greater proportion of those polled that are "indifferent" about the area's quality in Cordoba $(62 \%$ consider the area of medium quality) than in Tunja (49\%).

When asked about their perceived security, $96 \%$ of those polled in Cordoba considered the study area to be safe or very safe and only $4 \%$ considered it to be unsafe, while prior to the RENFE Plan social problems existed and caused this area to be unsafe [58]. On the contrary, 53\% of the people polled in Tunja considered the area to be unsafe ${ }^{7}$.

\section{CONCLUSIONS}

The methodology proposed in this article, based on dynamic and static analysis, provides a wide-ranging vision of the relationship among transport interchanges and the territorial dynamics in which they are integrated. This type of study enables to identify the interchange role on the local, regional and national scales, and also to integrate the territorial variables as part of the process, and not only as a consequence of the characteristics of the interchange.

The information required for the analysis of the specific effects transport interchanges is often difficult to obtain in historical series as it necessitates polls or specific data. In these cases, the proposed methodology, which reviews the historical dynamics of each city in a general context, is most effective. In these cases the only possibility to study certain influences of interchanges in their urban contexts is through detailed designed comparative analysis of several interchanges that are similar in some dynamic aspects and different in others, as applied in this article.

On the other hand, the compared analysis of two different cases has proven to be useful not only for a compared analysis, but it is mostly efficient for proving the versatility of the methodology for any type of city or transport interchange.

By examining both cases, using the methodology described, three main conclusions are drawn about aspects related to the urban environment of the interchanges, in terms of urban perception, quality and commercial density and the direct relation with the profile of travellers in each transport interchange.

Firstly, it was observed that the perception of urban space quality is strongly related to the degree of integration of interchanges within their city plan and to the innovative character of the transport technology. This aspect of image related to modernity contributes to reducing the "hate" aspect of transport interchanges and increasing the "love" ones in the classic attraction-repulsion relation. If a city plan involves suitable strategies to accommodate the interchange, then the perceived quality of the urban space seems no longer to depend on the transportation technology.

\footnotetext{
${ }^{7}$ In any case, since there is no similar information/studies for the whole cities of Córdoba and Tunja, this difference in security perception cannot be assumed to be objectively conclusive.
} 


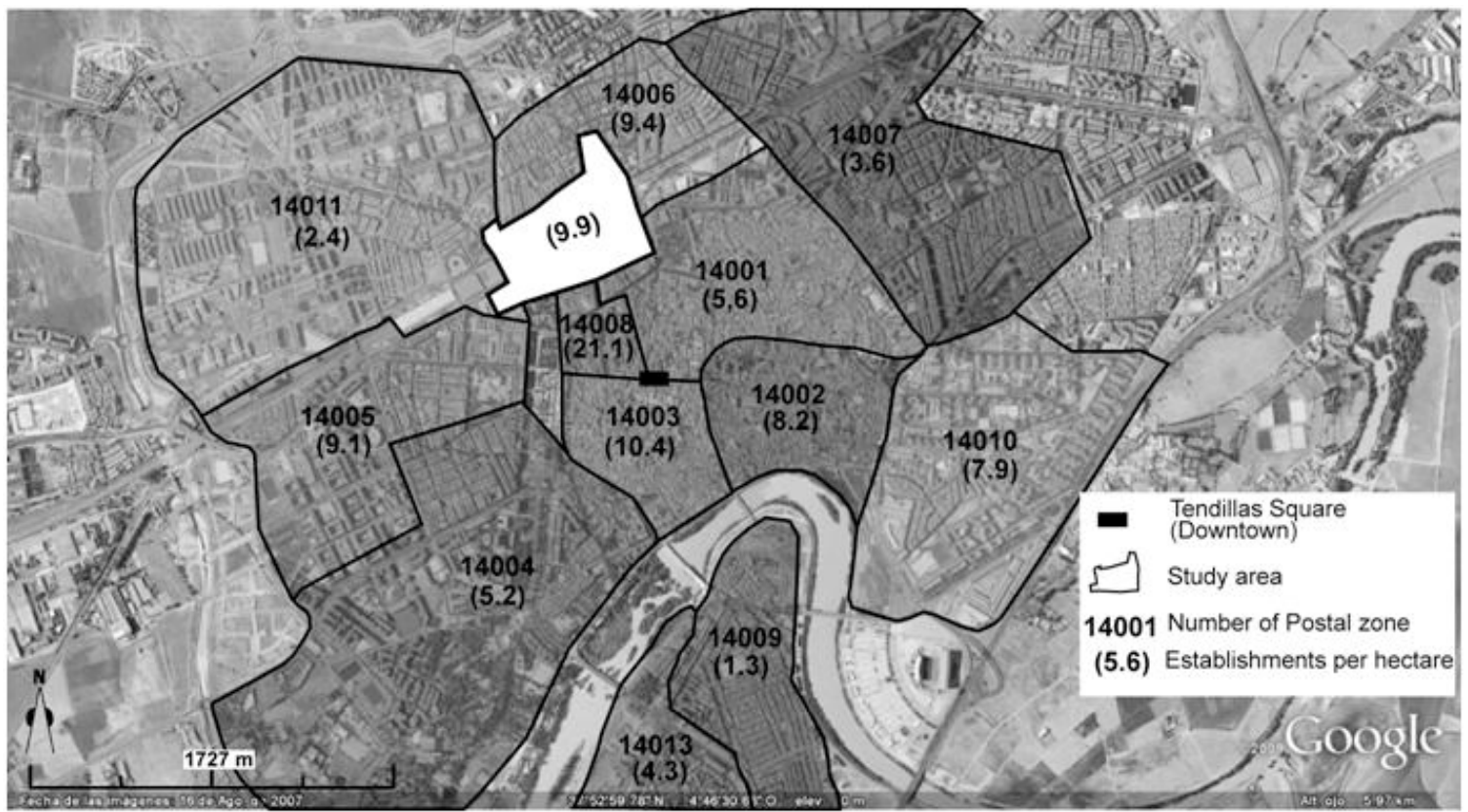

Fig. (4a). Commercial establishments per hectare, for each Zip Code zone in Cordoba - 2008. Sources: Chamber of Commerce of Cordoba and authors.

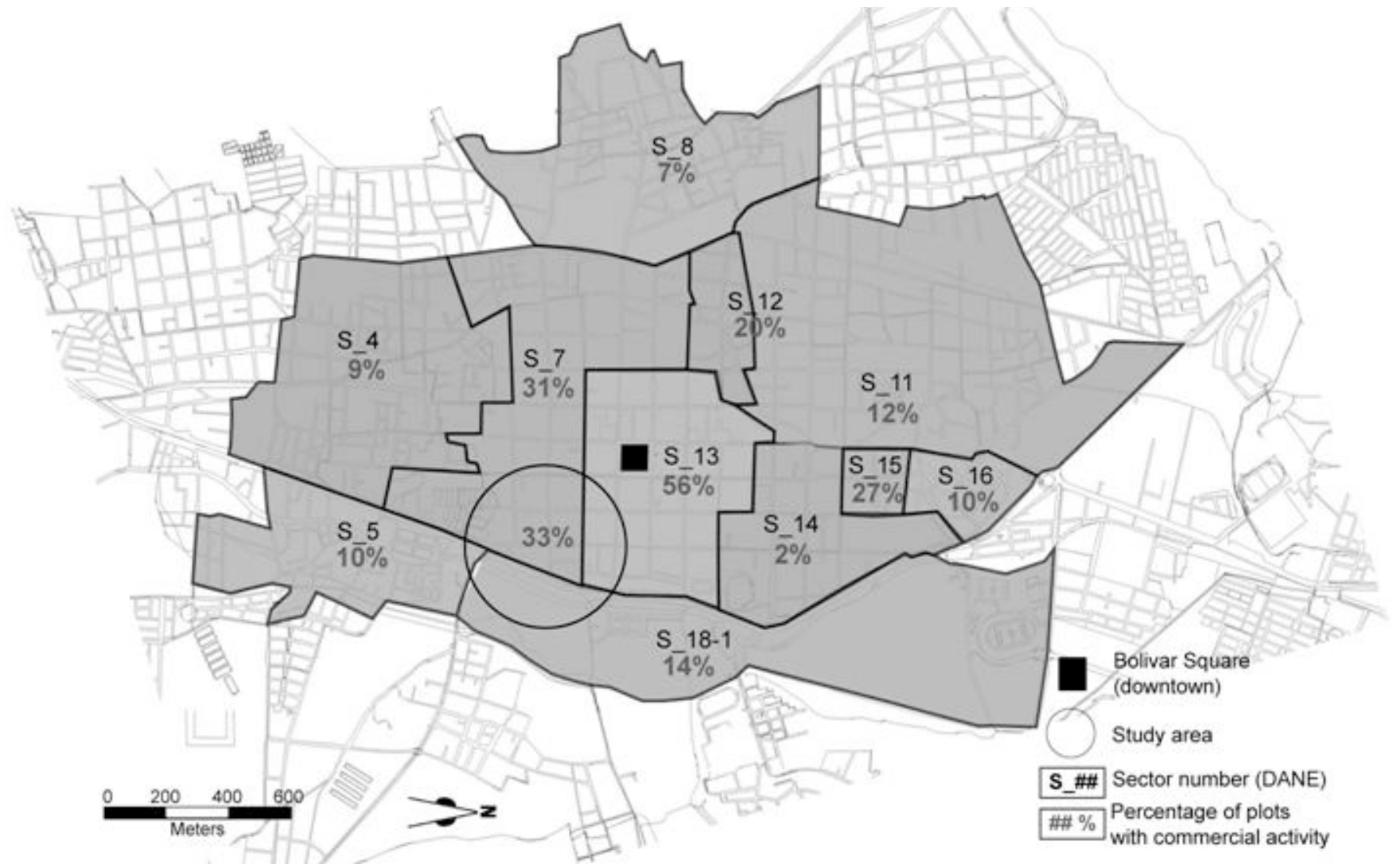

Fig. (4b). Percentage of plots with commercial activity in Tunja. Sources: DANE - Population and housing census - 2005 and authors.

Secondly, the study demonstrates that if transport interchanges are adequately integrated within the city plan, the types of commercial establishments are more related to the quality and capacity of the space around the interchange (that attracts people) than with the characteristics and users of the interchange. However, the interchange user's income level and the innovative character of new forms of more rapid transport modes influence the variety and quality of the economic activities not only inside, but also outside the interchange.

The article also shows that the areas around transport interchanges not far away from the city centre exhibit a higher density of commercial activities than the average 
commercial activity for the whole city. This density is lower than the city centre area but greater than in other areas as close to the city centre as the interchange. An increase in the proportion of restaurants, services and hotels was also noticed, which corresponds to the characteristics of a space that attracts important flows of people.

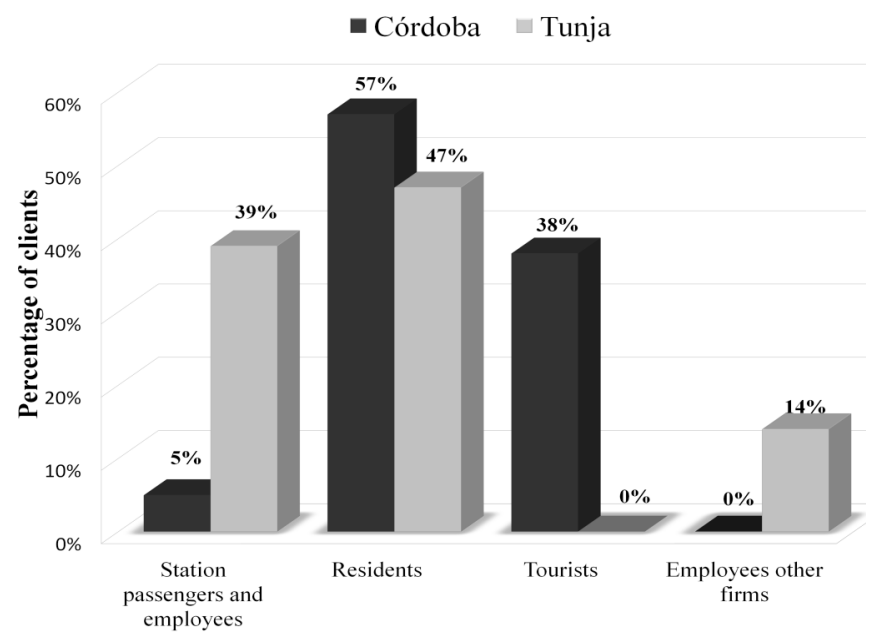

Fig. (5). Composition of the customers of existing establishments in the study areas. Source: authors - Survey of establishments in Córdoba (2009) and in Tunja (2008).

$$
\text { - Tunja Study area }
$$
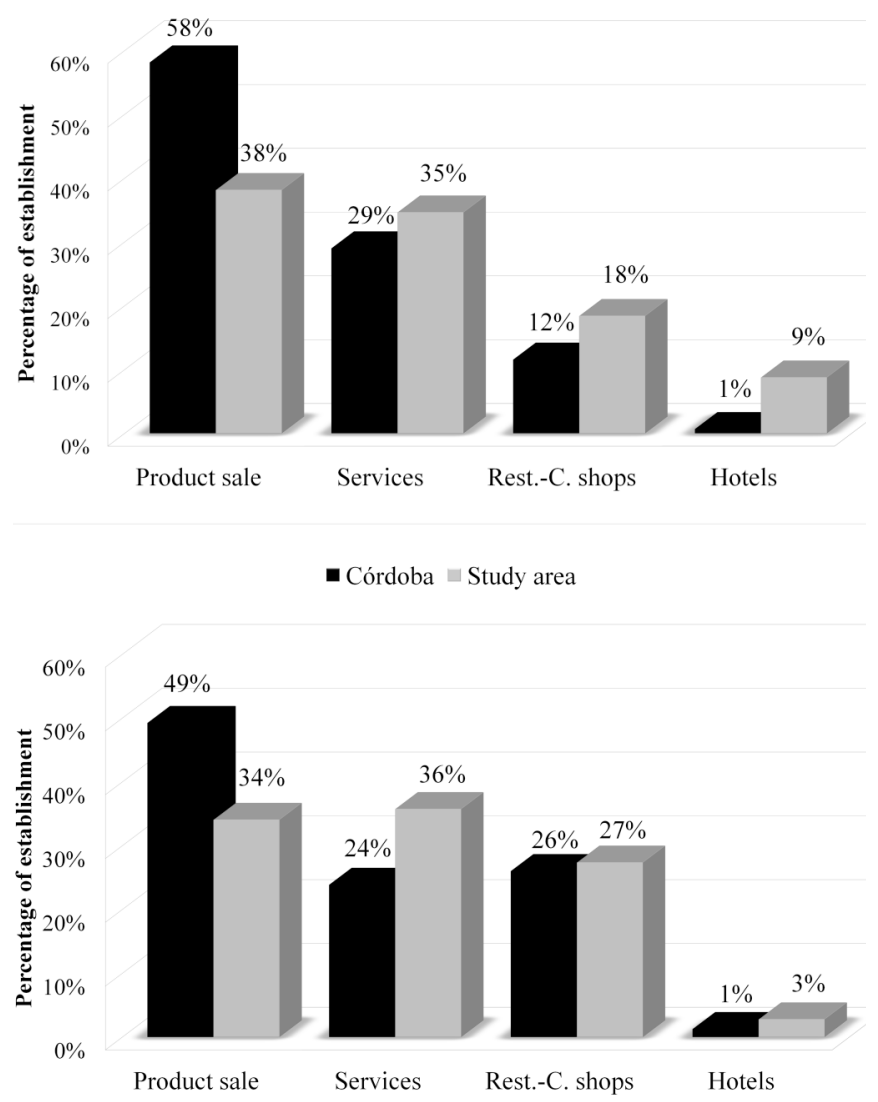

Fig. (6). Distribution of establishments according to the economic activity. Sources: Chamber of Commerce of Cordoba (2008) and authors - Plot inventory in Cordoba (2009).

It can be concluded that the amount and quality of commercial establishments that exist around interchanges in areas perceived as high quality is more related to the quality of the urban space generated by the city plan than to the amount of people attracted by transport interchanges. In contrast, when the transport interchange surroundings are perceived as lower quality than the city average, the commercial establishments take more advantage of the number and type of travellers and employees attracted by interchanges.

\section{ACKNOWLEDGEMENT}

Declared none.

\section{CONFLICT OF INTEREST}

Declared none.

\section{REFERENCES}

[1] Bertolini L. Nodes and places: complexities of railway station redevelopment. Eur Plann Stud 1996; 4(3): 331-45.

[2] Díaz SE, Ureña JM. El estudio del papel territorial de los intercambiadores de transporte: revisión y propuesta metodológica. Boletín de la Asociación de Geógrafos Españoles 2010; 54: 29-56.

[3] Plassard F. The relationship between regional policy and transport and communications networks. European conference of ministers of transport. Round Table 93. Lyon 1992.

[4] Offner JM. Les "effets structurants" du transport: mythe politique, mystification scientifique. Espace Géogr 1993; 3: 233-42.

[5] Biehl D. Role of infrastructure in regional development. In: Vickerman R, Eds. Infrastructure and regional development. London: European research in regional science, Pion Limited 1991; pp. 9-35.

[6] García-Mila T, McGuire T, Porter R. The effect of public capital in state-level production functions reconsidered. Rev Econ Stat 1996; 78(1): 177-80.

[7] Cantos P, Gumbau-Albert M, Maudos J. Transport infrastructures, spill over effects and regional growth: evidence of the Spanish case. Transp Rev 2005; 25(1): 25-50.

[8] Berechman J. Urban and regional economic impact of transportation investment: a critical assessment and proposed methodology. Transp Res A 1994; 28A(4): 351-62.

[9] Rephann T, Isserman A. New highways as economic development tools: an evaluation using quasi-experimental matching methods. Reg Sci Urban Econ 1994; 24: 723-51.

[10] Rietveld P. Spatial economic impacts of transport infrastructure supply. Transp Res A 1994; 28 A (4): 329-41.

[11] Gutiérrez J. El Tren de Alta Velocidad y sus efectos espaciales. Investigaciones Reg 2004; 5: 199-221.

[12] Banister D. Quantification of the non-transport benefits resulting from rail investment. 2nd International Seminar on Railway Planning. Seoul: Korea Railroad Research Institute, 2007. Available at: http://www.tsu.ox.ac.uk/pubs/1029-banister.pdf

[13] Bruinsma F, Rienstra S, Rietveld P. Economic impacts of the construction of a transport corridor: a multi-level and multi-approach case study for the construction of the A1 highway in the Netherlands. Reg Stud 1997; 31(4): 391-402.

[14] Herranz-Loncán A. Infraestructuras y desarrollo económico en el Pirineo Central (1850-2000). J Depopul Rural Dev Stud 2002; 2: 197-226.

[15] Bellet C, El impacto espacial de la implantación del tren de alta velocidad en el medio urbano. Rev Geogr 2002; 1: 57-77.

[16] Ribalaygua C, Garmendia M, Díaz SE, et al. Actividades en torno a estaciones de alta velocidad: metodología para su estudio. Geografía, territorio y paisaje: el estado de la cuestión: actas del XXI congreso de geógrafos españoles 2009; pp. 605-19.

[17] Enet-Dolowy. Impact de la mobilité sur les formes urbaines et architecturales. Paris, France: Ministère de l'Equipement, du Logement et des Transports 2004. Available at: http://www.innovati ons-transports.fr/Impact-de-la-mobilite-sur-les?lang=fr

[18] Garmendia M, Ureña JM, Ribalaygua C, Leal J, Coronado JM. Urban residential development in isolated small cities that are partially integrated in metropolitan areas by high-speed train. Eur Urban Reg Stud 2008; 15 (3): 265-80.

[19] Garmendia M, Ureña JM, Coronado JM. Long-distance trips in a sparsely populated region: the impact of high-speed infrastructures. J Transp Geogr 2011; 19(4): 537-51. 
[20] Wolfram M. Planning the integration of the high-speed train. A discourse analytical study in four European regions. PhD Thesis. Germany: Universität Stuttgart 2003. Available at: http://elib.unistuttgart.de/opus/volltexte/2004/1581/

[21] Cervero R. Rail transit and joint development. Land market impacts in Washington, D.C. and Atlanta. J Am Plann Assoc 1994; 60 (1): 83-93.

[22] Kim HK, Sohn DW. An analysis of the relationship between land use density of office buildings and urban street configuration. Cities 2002; 19(6): 409-18.

[23] Mannone V. Efectos espaciales de las estaciones del TGV implantadas en la periferia de las ciudades pequeñas. Revista Ingeniería y Territorio 2005; 70: 22-7.

[24] Willigers J, van Wee B. High-speed rail and office location choices. A stated choice experiment for the Netherlands. J Transp Geogr 2011; 19(4): 745-54.

[25] Kim K. High-speed rail developments and spatial restructuring. Cities 2000; 17(4): 251-62.

[26] Bosch R, Ulied A. Impactos territoriales y urbanísticos de la autopista A2 Zaragoza-Mediterráneo. Barcelona: Dirección General de Política Territorial y Urbanismo, Ministerio de Obras Públicas y Urbanismo, España 1993. Available at: http://www.mcrit.com/A2/index.htm

[27] Serrano R, Garmendia M, Coronado JM, Pillet F, Ureña JM. Análisis de las consecuencias territoriales del AVE en ciudades pequeñas: Ciudad Real y Puertollano. Estud Geogr 2006; 67(260): 199-229.

[28] Ureña JM, Menéndez JM, Guirao B, et al. Alta Velocidad ferroviaria e integración metropolitana en España: el caso de Ciudad Real y Puertollano. EURE 2005; 92: 87-104.

[29] Linneker B, Spence N. Road transport infrastructure and regional economic development. The regional development effects of the M25 London orbital motorway. J Trans Geogr 1996; 4(2): 77-92.

[30] Banister D, Hall S. Transport and city competitiveness - literature review. London: The Department for Transport (DfT) and Office of the Deputy Prime Minister (ODPM). 2004. Available at: http://webarchive.nationalarchives.gov.uk/+http://www.dft.gov.uk/p $\mathrm{gr} / \mathrm{scienceresearch} /$ social/transportandcitycompetitiven 1934

[31] Green R, James D. Rail transit station area development: small area modelling in Washington, D.C. Armonk, NY: M.E. Sharpe Publishers 1993.

[32] Bollinger $\mathrm{C}$, Ihlanfeldt $\mathrm{K}$. The impact of rapid rail transit on economic development: the case of Atlanta's MARTA. J Urban Econ 1997; 42: 179-204.

[33] Berg L, Pol P. The European high-speed train and urban development. Experiences in fourteen European urban regions. Rotterdam, The Netherlands: Ashgate 1998.

[34] Nelson A. Transit stations and commercial property values: a case study with policy and land-use implications. J Public Transp 1999; 2(3): 77-95.

[35] Hess D, Almeida T. Impact of proximity to light rail rapid transit on station-area property values in Buffalo, New York. Urban Stud 2007; 44(5/6): 1041-68.

[36] Anderssona DE, Shyrb OF, Fub J. Does high-speed rail accessibility influence residential property prices? Hedonic estimates from southern Taiwan. J Transp Geogr 2010; 18(1): 166-74.

[37] Bertolini L, Spit T. Cities on rails, the redevelopment of railway station areas. London/New York: E \& FN Spon 1998.

[38] Pol P. A renaissance of stations, railways and cities. Economic effects, development strategies and organisational issues of European high-speed-train stations. Delft: DUP Science 2002.

[39] Ureña JM, Menerault P, Garmendia M. The high-speed rail challenge for big intermediate cities: a national, regional. Cities 2009; 26: 26679.
[40] Bajard M, Bonvalet N, Hitter G, Barroux B, Peuchant F. Atlas des pôles d'échanges. Appréhender l'organisation spatiale des lieux de la mobilité. París, France : PREDIT 1999.

[41] Grebert J, Toupin F, Beauvais JM. Les petites gares du périurbain en région tourangelle: continuité territoriale et rupture de charge. Paris: Atelier d'urbanisme de Tours, rapport. Paris, France: PREDIT 1999.

[42] Said V, Santoire V, Hengoat D. Étude de densification/valorisation des quartiers autour des stations de transport en commun. Paris, France: 1AURIF 2001.

[43] Menerault P. Les pôles d'échanges en France État des connaissances, enjeux et outils d'analyse. Paris: Centre d'Études sur les réseaux, les transports, l'urbanisme et les constructions publiques 2006.

[44] Lambooy J. Stationslokaties op weg naar morgen. The Netherlands, Amersfoort: Congress stationslokaties 1994.

[45] Bourgeois F, Barthelemy J, Liotard M, Guyon P. Les gares, locomotives du développement urbain? 1- Réflexion méthodologique à partir de cas français et étrangers. 2- Monographies: Lyon Perrache, Marseille - Saint-Charles; Paris, France 1997.

[46] Ribalaygua C. Alta velocidad ferroviaria y ciudad: Estrategias de incorporación de las nuevas estaciones periféricas francesas y españolas. Cuadernos de Investigación Urbanística. Escuela Técnica Superior de Arquitectura de Madrid; Madrid, España 2005. Available at: http://www.aq.upm.es/Departamentos/Urbanismo/publicaciones/ciur44. pdf

[47] Ureña JM, Ribalaygua C, Coronado JM, Escobedo F, Garmendia M. Situaciones y retos territoriales de la Alta Velocidad Ferroviaria en España. Ciudad y Territorio. Estud Territoriales 2006; 148: 397-427.

[48] Godard X. Pôles d'échanges actuels et en projets dan l'aire métropolitaine marseillaise (AMM). Cahiers Villes et territoires méditerranéens, Définitions et questionnements autour des pôles d'échanges. Paris, France 2001.

[49] Soulas C. Les services dans les pôles d'échanges: les enjeux d'une problématique en développement. In: Menerault P, Ed. Les pôles d'échanges en France. Etat des connaissances, enjeux et outils d'analyse. Paris: Centre d'Etudes sur les réseaux, les transports, l'urbanisme et les constructions publiques 2006; pp. 74-9.

[50] Burckhart K. Alemania: actuación urbana y actividades en las estaciones de alta velocidad. II Jornada Europea sobre Alta Velocidad y Territorio. Ciudad Real: Universidad de Castilla-La Mancha; Ciudad real, Spain 2007. Available at: http://www.uclm.es/cr/cami nos/publicaciones/Cuaderno_Ing_Territorio/libros/cuaderno12/2.pdf

[51] Sands B. The development effects of high-speed rail stations and implications for California. Berkeley: Institute of Urban and Regional Development. University of California: California, USA 1993.

[52] Vickerman R. Recent evolution of research into the wider economic benefits of transport infrastructure investments. OECD/ITF Joint Transport Research Centre Discussion Papers, 2007.

[53] Rietveld P. Infrastructure and regional development. A survey of multiregional economic models. Ann Reg Sci 1989; 23: 255-74.

[54] Weisbrod G. Current practices for assessing economic development impacts from transportation investments. A synthesis of highway practice. Washington, D.C: Transportation Research Board 2000.

[55] De Courson J, Remond E, Jaquen M. Gares TGV et Urbanisme. Étude sur neuf agglomérations des impacts d'une gare TGV. París, France: Ministère de l'Équipement, du Logement et des Transports 1993.

[56] Lynch K. The Image of the city. Cambridge: MIT Press 1960.

[57] Arefi M, Meyers W. What is public about public space: the case of Visakhapatnam, India. Cities 2003; 20(5): 331-9.

[58] Typsa. Efectos de la línea de Alta Velocidad Madrid-Sevilla sobre la movilidad, el sistema territorial y el desarrollo regional, Ministerio de Fomento, Madrid. Unpublished results 2002. 